\title{
РОЗВИТОК МОТИВАЦІЇ ЯК УМОВА ОРГАНІЗАЦЇ̈ ПІЗНАВАЛЬНОЇ ДІЯЛЬНОСТІ СТУДЕНТІВ ВИЩИХ НАВЧАЛЬНИХ ЗАКЛАДІВ У ПРОЦЕСІ НАВЧАННЯ ГУМАНІТАРНИХ ДИСЦИПЛІН
}

Автор статті досліджує процес розвитку мотиваційної сфери студентів і виокремлює ї̈ як об'єктивну умову організації пізнавальної діяльності студентів вищих навчальних закладів.

Ключові слова: організація пізнавальної діяльності студентів, мотивація, пізнавальна мотивація, формування мотивації, розвиток мотивації.

Автор статьи исследует процесс развития мотиваџионной сферь студентов и выделяет ее в качестве объективного условия организации познавательной деятельности студентов высших учебных заведений.

Ключевые слова: организация познавательной деятельности студентов, мотивация, познавательная мотивация, формирование мотиваџии, развитие мотивации.

The author of the article investigates the process of development of motivational sphere of students and distinguishes it as an objective condition of the organization of cognitive activity of students of higher educational establishments.

Key words: organization of cognitive activity of students, motivation, cognitive motivation, forming of motivation, development of motivation.

Держава ставить перед системою вищої освіти завдання підготовки компетентного фахівця, що вміє самостійно мислити, здобувати і застосовувати знання на практиці в умовах модернізації і технологізації сучасного суспільства.

Вища освіта покликана не тільки озброювати майбутніх фахівців професійно значущими знаннями, уміннями і навичками, але й розвивати у студентів здібність до подальшого самостійного оволодіння зростаючою кількістю нової інформації. У зв’язку з цим проблема організації пізнавальної діяльності студентів вищих навчальних закладів набуває особливої актуальності і є важливою умовою формування у студентів потреби в знаннях, розумової активності, самостійності, забезпечення глибини й міцності знань. 
Результативність процесу організації пізнавальної діяльності студентів у процесі навчання гуманітарних дисциплін залежить від наявності й дотримання певних умов.

За визначенням, що подається у філософському словнику, «умова - це філософська категорія, яка виражає відношення предмета до явищ, що оточують його, без яких він існувати не може. Сам предмет виступає як щось обумовлене, а умова - як відносно зовнішне до предмета різноманіття об'єктивного світу» [14, с. 425].

Умови здебільшого розглядаються як щось зовнішне для явища, на відміну від більш широкого поняття «причини», що включає як зовнішні, так і внутрішні чинники. У педагогіці умови, які не є самі по собі причиною подій, у той же час підсилюють або послаблюють дії причини. Відтак умови визначаються як чинники, обставини, від яких залежить ефективність функціонування педагогічної системи [10].

Сучасна дидактика тлумачить умови як сукупність чинників, компонентів навчального процесу, що забезпечують успішність навчання. Так, К. Біктагіров зазначає: «... Під дидактичними умовами навчання розуміють таку обстановку (обставини), за якої компоненти навчального процесу (навчальний предмет, викладання і навчання) представлені в найкращому взаємовідношенні, і яка дає можливість учителеві плідно викладати, керувати навчальним процесом, а тим, хто навчається, - успішно навчатися» [1, с. 61]. У цьому визначенні акцентовано на основному призначення дидактичних умов.

Відомо, що основним організаційним моментом пізнавальної діяльності $є$ розвиток мотивації до вивчення певного предмета або циклу навчальних дисциплін (у нашому випадку - гуманітарних). Розвиток пізнавальної мотивації забезпечує подолання труднощів студентами в навчальній роботі, стимулює їх пізнавальну активність та ініціативу. Із появою пізнавальної мотивації відбувається перебудова психологічних процесів сприйняття, пам'яті, мислення й інших можливостей тих, хто навчається, які впливають на ефективність процесу навчання.

Отже, метою статті є дослідження розвитку мотивації як умови організації пізнавальної діяльності студентів вищих навчальних закладів у процесі навчання гуманітарних дисциплін. 
Питання мотивації навчання як засобу досягнення результативності навчально-виховного процесу завжди були предметом інтересу вчених. Я. Коменский, Я. Корчак, А. Макаренко, В. Сухомлинський, К. Ушинський акцентували на використанні у змісті навчального матеріалу життєвих ситуацій, на необхідності створення сприятливого емоційного мікроклімату в аудиторії.

Вагомий внесок $\mathrm{y}$ розкриття теоретичних аспектів мотивації навчальної діяльності здійснили А. Асмолов, Л. Божович, Л. Виготський, А. Золотих, Г. Костюк, В. Леонтьєв, А. Маркова, М. Матюхіна, В. Моргун, А. Нісімчук, О. Падалка, Д. Рассел, Х. Хекхаузен та ін., які зосереджували увагу на дослідженні особливостей побудови мотиваційної сфери індивіда, етапів формування мотивів та механізмів їх функціонування у свідомості людини, інтенсифікації та оптимізації педагогічного процесу.

Загалом мотивація визначається як система різних компонентів, що передбачають потреби, мотиви, мету, інтереси, емоції тощо. Проте аналіз наукової літератури показує, що до питання вивчення мотивації дослідники підходять порізному.

Пізнавальну мотивацію, що пов'язана зі змістом навчальної діяльності і процесом її виконання, А. Маркова поділяє на кілька підгруп:

- широкі пізнавальні мотиви, що полягають в орієнтації тих, хто навчається, на оволодіння новими знаннями;

- навчально-пізнавальні мотиви, що полягають в орієнтації тих, хто навчається, на засвоєння способів здобування знань, інтересу до прийомів самостійного набуття знання, методів наукового пізнання, способів саморегуляції навчальної роботи, раціональної організації своєї навчальної праці;

- мотиви самоосвіти, що полягають у спрямованості тих, хто навчається, на самостійне вдосконалення способів одержання знань [8, с. 12].

Співвіднесемо ці види мотивів із різними виявами пізнавальної активності студентів.

Широкі пізнавальні мотиви виявляються в успішному виконанні навчальних завдань, прагненні до пізнання нового; навчально-пізнавальні мотиви - в зацікавленості студентів у навчальній діяльності, активності на заняттях; мотиви самоосвіти виявляються в готовності студентів самостійно здобувати знання, виконувати самостійну роботу. О. Матюшкін 
стверджує, що пізнавальна мотивація, будучи відносно самостійним чинником, визначає тип і рівень пізнавальної активності людини. Сама пізнавальна мотивація характеризується ним як така, що виступає первинно у вигляді ситуативно виникаючої пізнавальної потреби, яка породжується умовами конкретного завдання, особливостями спілкування й міжособистісної взаємодії [9].

Пізнавальна потреба є безпосереднім механізмом пізнавальної мотивації. Психофізіологічні основи потреб глибоко розкриті в роботах П. Гальперіна. Він розглядає потребу як спонуку, прагнення до мети. Основою формування пізнавальної потреби, на думку П. Гальперіна, є усвідомлення суперечності - між новим фактом і наявним запасом знань [5].

Особлива увага питанням виховання пізнавальної потреби приділена в роботах провідних дидактів М. Данилова [7] і М. Скаткіна [12]. Так, М. Данилов вказує на особливий взаємозв'язок і взаємозумовленість пізнавальної потреби й пізнавальної активності [7].

Велику роль у розвитку мотивації відіграє інтерес. Проте і він не завжди може спонукати до активної діяльності. Про мотивацію ми говоримо тоді, коли зацікавленість та інтерес приводять до конкретної діяльності, стають іiі мотивами. «Високий ступінь мотивації навчальної діяльності означає, що зацікавленість у ній сприяла вияву вольових зусиль, досить дієвих, щоб здолати всі внутрішні й зовнішні перешкоди. Ступінь мотивації - це ступінь зацікавленості, що викликає активність» [6].

Формування мотивації до предмета, що вивчається, - необхідний процес. Особливо це стосується вивчення тих предметів, які не є профілюючими, адже їм не приділяється достатньо часу, і більше того, студенти часто не знаходять сенсу у вивченні цих предметів, оскільки не бачать зв'язку з майбутньою професією. Якщо говорити про гуманітарні науки, то прикладом може слугувати іноземна мова. Специфічна роль мотивації у іiі вивченні полягає в тому, що у зв'язку зі зміщенням акценту в навчанні на оволодіння мовною діяльністю i формування комунікативної компетенції стає важливою активна роль самого суб'єкта в процесі навчання, а це можливо лише за наявності високого рівня мотивації в студента.

Необхідно розвинути передусім загальну мотивацію до вивчення мови, якщо вона відсутня. Студенти повинні бачити й розуміти, яке важливе значення має знання іноземної 
мови в житті - це і спілкування з представниками інших країн, і ознайомлення з культурою іншомовних народів, i, нарешті, доступ до величезного числа інформаційних джерел. Проте загальної мотивації недостатньо для розвитку активності. Потрібно, щоб уся навчальна діяльність студента була мотивованою, тому необхідно розвивати і професійну мотивацію.

Мотивація позитивно впливає на всі психічні процеси особистості - увагу, сприйняття, пам'ять, уявлення й уяву, мислення. У зв'язку з цим ми розглядаємо мотивацію як одну 3 дидактичних умов організації пізнавальної діяльності студентів.

Увага з'являється передусім до того, що представляє інтерес для особистості. Інтерес - одна 3 найдієвіших спонук уваги як довільної, так і мимовільної. Увага до об'єкта спостерігається в тих випадках, коли він має особистісну значущість для студента. Важливу роль у цьому процесі відіграє постановка мети, яка викликає активну й інтенсивну увагу.

Сприйняття навчального матеріалу часто залежить від сформованості пізнавальної потреби, пов'язаної з перцептивною настановою, тобто інструкцією, яка сприяє правильному і точному сприйняттю інформації.

Процес мислення зумовлюється мотивами суб'єкта. Підкреслюючи необхідність мотивації для розумової діяльності особистості, Л. Виготський писав: «Сама думка народжується не $з$ іншої думки, а з мотивуючої сторони нашої свідомості» [4, с. 156]. Мислення як особливий вид психічної пізнавальної діяльності суб'єкта регулюється системою активних ставлень суб'єкта до предмета, що виражаються в мотивації розумової діяльності. Мотивація детермінує тип, характер, спрямованість, продуктивність мислення й залежить від ступеня активності суб'єкта.

Розумова діяльність неможлива без активності емоційновольової сфери особистості. Вона вимагає зосередженості й сконцентрованості уваги на об'єкті пізнання і практичних діях. В. Буряк називає розумову активність найважливішою ознакою правильно організованої пізнавальної діяльності. Розумова активність виявляється в цілеспрямованому аналізі й синтезі, узагальненні й абстрагуванні, класифікації й систематизації навчального матеріалу, у міркуваннях, висновках, у застосуванні індукції і дедукції, в обгрунтуванні тверджень, в оволодінні системою знань [2, с. 74]. 
У дослідженні взаємозв'язку мотивації й мислення відзначається, що мислення виявляється у двох нерозривно пов'язаних якостях - процесуальній і особистісній. Особистісний аспект мислення складають передусім мотивація і здібності людини (тобто іiі ставлення до завдання, що розв'язується, до інших людей тощо, у чому виявляються i формуються спонуки до розумової діяльності і іï розумові здібності). Значущість мотивації $є$ передумовою активізації розумового процесу, зміни його динамічної напруженості, що створюється тією додатковою енергією процесу, яка забезпечується включенням мислення в іншу структуру ставлення суб'єкта до середовища.

$€$ різні мотиви мислення: внутрішні (власне пізнавальні мотиви, пов'язані зі змістом і процесом мислення) і зовнішні (зовнішні за відношенням до процесу мислення). Найбільш ефективною $є$ власне пізнавальна мотивація, оскільки вона забезпечує повноцінну розумову діяльність [11, с. 109].

Пізнавальні мотиви в оволодінні іноземною мовою диференціюються отже: інтерес до мови сприяє формуванню мотивів до аналізу мовних явищ, розвитку лінгвістичного мислення; можливість використання мови як засобу обміну інформацією, отримання знань, зокрема професійних, формує мотив ставлення до іноземної мови як до необхідного засобу пізнавальної діяльності.

П. Гурвич і С. Григорян визначають такі види мотивації під час оволодіння іноземною мовою:

а) цільова (комунікативна) мотивація;

б) мотивація, породжена усвідомленням тими, хто навчається, досягнутого прогресу в оволодінні мовою або ж окремими аспектами;

в) мотивація, породжена емоційно-особистісним інтересом до країни, мова якої вивчається (країнознавча мотивація);

г) пізнавальна мотивація, породжена інтересом до більш глибокого осмислення мовної форми;

д) мотивація, зумовлена прагненням до отримання інформації в якнайповнішому обсязі й певній системі;

е) мотивація, породжена почуттям задоволення, яке отримується при виконанні певних видів роботи (вправ) (інструментальна мотивація); 
ж) мотивація, породжена почуттям естетичного задоволення, яке ті, хто навчається, отримують при виконанні навчальних дій (естетична мотивація) [6].

М. Васильєва виокремлює два види позитивної мотивації під час вивчення іноземної мови:

- перспективна мотивація, яка пов'язана $з$ усвідомленням віддалених цілей навчання, його корисності для майбутньої роботи. Для розвитку цього виду мотивації в процесі навчальної діяльності студентам роз'яснювалося, яке значення має іноземна мова для їхньої майбутньої професійної діяльності. Це і спілкування з колегами на міжнародних змаганнях, і можливість роботи за кордоном, і читання професійної літератури (газет, журналів) іноземною мовою, і можливості користування іншомовними сайтами мережі Інтернет;

- процесуальна мотивація, тобто «мотиви дій», що зумовлюються зацікавленістю студентів у виконанні навчальних дій (особливо значуща, оскільки забезпечує високий рівень пізнавальної активності) [3].

Висока процесуальна мотивація студентів, яка 3'являється під час проведення мовленнєвої практики, має тенденцію поширюватися на весь процес вивчення іноземної мови. Переконавшись у тому, що іноземна мова $\epsilon$ реальним засобом спілкування, за допомогою якого можна виявити себе як особистість, студент починає інакше ставитися до всіх інших підготовчих форм роботи (умовно-мовленнєвих вправ, пояснення правил тощо). Вони починають сприйматися як необхідна передумова отримання можливості брати участь у діяльності, що стала привабливою для студентів, а саме - іншомовній мовленнєвій комунікації. Як наслідок, зростає активність студентів у всіх ланках навчального процесу [13].

Розвиток мотивації багато в чому залежить від того, якими методами й засобами користується викладач, як він організує діяльність студентів. Слід зазначити, що педагог має бути талановитим режисером, щоб поставити хорошу виставу під назвою заняття з іноземної мови. Дотримання певних умов, у яких процес навчання стає психологічно цікавим і таким, що спонукає до одержання знань, сприяє розвитку мотивації.

Слід пам'ятати, що у студента викликає інтерес передусім те, що стосується його особистості. Тому викладачеві важливо, дотримуючись особистісно зорієнтованого підходу, вивчити інтереси кожного студента, його досягнення. Про наявність високої мотивації можна судити 3 рівня діяльності 
студентів: відвідування занять, зацікавленості і успішності навчання. Показником відсутності мотивації може бути пасивність студентів на заняттях, небажання виконувати завдання, байдужість до навчального процесу.

Можна зробити висновок, що мотивація є вирішальним чинником стимуляції розумового процесу тих, хто навчається. Чим вищий рівень мотивації, тим результат навчання ефективніший. Студенти, у яких мотивація знаходиться на більш високому рівні, - активніші й діяльніші, їхні розумові процеси продуктивніші, а дії з оволодіння навчальним матеріалом більш усвідомлені. Отже, активність розумових процесів студентів, а відтак активність їхньої пізнавальної діяльності залежить від рівня сформованості мотиваційної сфери.

Напрямок подальших досліджень убачаємо в пошуку й дослідженні інших дидактичних умов, дотримання яких $\epsilon$ необхідним в організації пізнавальної діяльності студентів вищих навчальних закладів у процесі навчання гуманітарних дисциплін.

\section{Література}

1. Биктагиров К. Л. Дидактические условия обучения татарскому языку : дис. ... канд. пед. наук : спец. 13.00.01 «Общая педагогика и история педагогики» / К. Л. Биктагиров. - Казань, 1973. - 286 с. 2. Буряк В. К. Активность и самостоятельность учащихся в познавательной деятельности / В. К. Буряк // Педагогика. - 2007. - №8. - С. 71-78. 3. Васильева М. М. Условия формирования мотивации при изучении иностранного языка / М. М. Васильева // ИЯШ. - 1981. - №2. - С. 41-45. 4. Выготский Л. С. Проблемы общей психологии Л. С. Выготский; под ред. В.В.Давыдова // Собр. соч. - М. : Педагогика, 1988. - Т. 2. - 504 с. 5. Гальперин П. Я. Методы обучения и умственного развития / П. Я. Гальперин. - М. : МГУ, 1985. - 45 с. 6. Гурвич П. Б. Усиление мотивации учебной деятельности, направленной на овладение лексикой иностранного языка / П. Б. Гурвич, С. Т. Григорян // Иностранный язык в школе. - 1976. - №5. - С. 50-58. 7. Данилов М. А. Дидактика [учеб. пособие] / М. А. Данилов, Б. П. Есипов. - М. : Педагогика, 1957. 518 с. 8. Маркова А. К. Формирование мотивации учения в школьном возрасте : [пособ. для учит.] / А. К. Маркова. - М. : Просвещение, 1983. - 96 с. 9. Матюшкин А. М. Психологическая структура, динамика и развитие познавательной активности / А. М. Матюшкин // Вопросы психологии. - 1982. - №4. - С. 5-17. 10. Педагогическая энциклопедия : в 4 т. / гл. ред. И. А. Каиров. М. : Советская энциклопедия, 1966. - Т. 3. - 879 с. 11. Познавательные процессы и способности в обучении: [учеб. 
пособ. для студентов пед. ин-тов] / под ред. В. Д. Шадрикова. М. : Просвещение, 1990. - 142 с. 12. Скаткин М. Н. Активизация познавательной деятельности учащихся в обучении / М. Н. Скаткин. - - М. : Педагогика, $1965 . \quad$ - 175 с. 13. Тарнопольский О. Б. Методика обучения английскому языку на 1 курсе технического вуза / О. Б. Тарнопольский. - К. : Вища школа, 1989. - 158 с. 14. Философский словарь / под ред. М. М. Розенталя. - [3-е изд.]. - М. : Политиздат, 1975. - 496 с.

Г. В. Даниліна, кандидат техн. наук, доцент, Криворізький коледж Національного авіаційного університету

\section{ФОРМУВАННЯ У СТУДЕНТІВ ТЕХНІЧНИХ СПЕЦАЛЬНОСТЕЙ ПРИЙОМІВ НАВЧАЛЬНОӤ ДІЯЛЬНОСТІ ПІД ЧАС ВИВЧЕННЯ МАТЕМАТИКИ}

У статті конкретизовано сутність поняття «прийом навчальної діяльності»; подано зміст, класифікачії, иляхи й засоби, наявні методи формування у студентів технічних спеціальностей прийомів навчальної діяльності під час вивчення математики.

Ключові слова: прийом навчальної діяльності, алгоритм, евристична схема.

В статье конкретизируется сущность понятия «прием учебной деятельности»; подается содержание, классификации, пути и средства, существующие методы формирования у студентов технических специальностей приемов учебной деятельности при изучении математики.

Ключевые слова: прием учебной деятельности, алгоритм, эвристическая схема.

In article the essence of concept «reception of educational activity» is concretized; the content, classifications, ways and the means, existing methods of formation at students of technical specialities of receptions of educational activity moves at mathematics studying.

Key words: reception of educational activity, algorithm, the heuristic scheme.

Курс математики для студентів технічних спеціальностей відіграє одну 3 провідних ролей у професійній підготовці. Цьому аспекту приділено належну увагу в концепції змісту вищої освіти (В. Андрущенко, Р. Гуревич, І. Зязюн, I. Козловська, В. Кремень, Н. Ничкало, С. Сисоєва та ін.); методиці навчання математики студентів різних спеціальностей (I. Акуленко, М. Башмаков, В. Бевз, Г. Бевз, О. Глобін, Н. Глузман, В. Гусєв, Г. Дорофєєв, Ю. Колягін, Т. Крилова, Д. Пойя, Г. Саранцев, С. Семенець, О. Скафа, 3. Слєпкань, Н. Тарасенкова, В. Таточенко, Т. Хмара, В. Швець та ін.). 